richness of fish species ${ }^{3}$.

Dulal Goswami, an environmental scientist at Gauhati University in Guwahati, Assam, worries that the geological hazards of the region have not been properly considered. "The Himalayas are fragile and dynamic," he says. Earthquakes of magnitude 7 or 8 are not uncommon, and increasing glacial melts due to climate change are causing more floods, both of which can damage dams and tunnels.

And the rivers' heavy sediment loads could clog the dams. According to Goswami, the Brahmaputra carries 400 million tonnes of sediment each year, peaking at 25 million tonnes a day during extreme monsoon events.

The Indian government has required EIAs for the projects, but these are lax, says Neeraj Vagholikar, a conservationist at the non-governmental organization Kalpavriksh in Pune. For example, he says, the EIA of a dam project on the Siyom River lists just five bird species in an area that ecologists say has more than 300 ; similarly, the EIA for the Lower Subansiri dam lists 55 fish species in a river that has at least 156.

The assessments usually cover a radius of only 10 kilometres from the dam and reservoir, and do not consider downstream effects or secondary impacts caused by the influx of labour and infrastructure such as power lines. And the cumulative impact of multiple dams along the

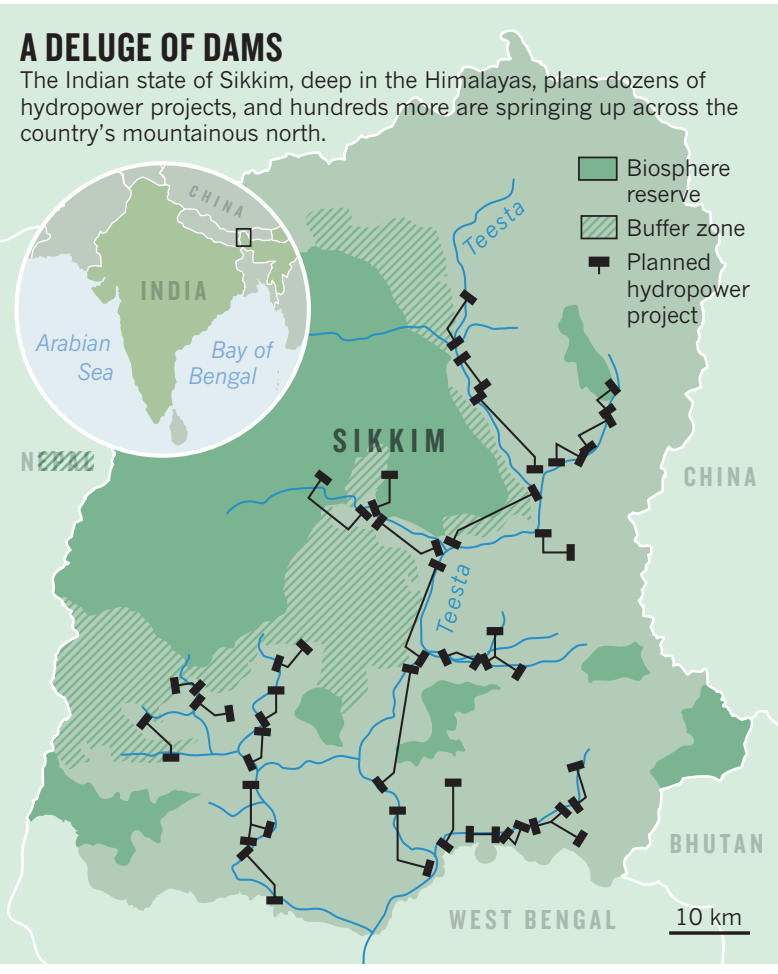

river may be serious, he says. "It's based on such poor assessments that $99 \%$ of the projects get approved," adds conservationist Samir Mehta, south Asia programme director of International Rivers, a non-governmental organization based in Berkeley, California.

Some also argue that the assessments are not sufficiently independent. "Agencies that conduct the EIAs are selected and paid for by dam developers and deliver favourable assessments in order to be invited back," says Mehta. The Ministry of Environment and Forests did not respond to Nature's questions about the allegations.

India is not alone in its rush to build dams in the Himalayas. Other countries, especially China, Pakistan, Nepal and Bhutan, plan to add hundreds more dams along the rivers, prompting similar concerns about their EIAs. Damming rivers upstream could have significant impacts on downstream nations, but "every country behaves as if the river is $100 \%$ theirs", says Edward Grumbine, an environmentpolicy researcher at the Chinese Acadsame river is not assessed before individual projects are approved. "This is particularly important for areas with densely clustered dams," says Bawa. Even if the impacts of individual projects are acceptable, the cascading effects on ecosystems and the geological hazards of dams stacking on top of one another along the same emy of Sciences' Kunming Institute of Botany. "This is a recipe for disaster."

1. Bawa, K. et al. Science 327, 1457-1478 (2010).

2. Pandit, M. K. \& Grumbine, E. Conserv. Biol. 26 , 1061-1071 (2012).

3. Bhatt, J. P., Manish, K. \& Pandit, M. K. PLoS ONE 7, e46237 (2012).

MATERIALS

\title{
Nanoparticle blast caught on film
}

\section{Combustion could help to make minuscule matter.}

\section{BY EUGENIE SAMUEL REICH IN BOSTON}

$\mathrm{I}$ $t$ was a pretty explosive premiere for a movie about a chemical reaction. A microscopic droplet drifted across the screen - almost in homage to the panning gun barrel of the James Bond movies - and then: bang!

Scientists watching the scene last week at a meeting of the Materials Research Society (MRS) in Boston, Massachusetts, were gripped, because the death of the droplet was also an act of creation. Lutz Mädler, a process engineer at the University of Bremen in Germany, had, for the first time, captured on camera a process that makes beautifully homogeneous metal oxide nanoparticles (see 'Blow up'). His goal is to pave the way for faster, cheaper ways to make these fragments of matter, measuring just billionths of a metre across, which are finding uses as catalysts, medical imaging probes and more.

Mädler's presentation was part of the first MRS session ever to be dedicated to the combustion synthesis of nanoparticles. The technique aims to improve the process of making nanoparticles, which generally requires multiple, complex steps from expensive precursors. The solution, say Mädler and others, is to create the particles in bulk by simply igniting tiny droplets of precursor materials - a strategy that industry has used for decades to make carbon black for tyres and silica for optic fibres.

"This is a field that mushroomed out of industry, and didn't have an academic following," says Sotiris Pratsinis, a process engineer at the Swiss Federal Institute of Technology (ETH) Zurich. "These are beautiful fundamental studies.”

Mädler's work aims to overcome a key drawback of combustion synthesis: the process is little understood and tends to be poorly controlled. In 2002, and working with Pratsinis, Mädler developed a way to make metal oxide nanoparticles by burning organometallic complexes dissolved in organic solvents (L. Mädler et al. J. Aerosol Sci. 33, 369-389; 2002). The approach worked well in the lab, but the ingredients were too expensive for most commercial applications. Mädler resolved to pick apart the process so that he could replicate it with cheaper precursors, such as metal nitrates, which can be produced directly from ores.

At present, metal nitrates yield nanoparticles that are inhomogeneous - often with hollow areas inside - but Mädler says that his high-speed videos reveal how mixing processes in the combustion of organic 
droplets help to make the particles more homogeneous. That should enable researchers to choose better precursors and additives that could improve combustion, and yield better-quality end products, says Karsten Wegner, a process engineer and consultant also at ETH Zurich. More and more chemicals companies are asking Wegner for advice on ways to scale up nanoparticle combustionsynthesis processes, he says, and the range of nanomaterials they want to make in large quantities is growing exponentially.

As industry explores the commercial appeal of the technique, researchers are turning to it to create specialized nanoparticles that can be tailored to medical imaging, sensing or toxicity studies. Ian Kennedy, a mechanical engineer at the University of California, Davis, is using combustion to make nanoparticles that contain europium, an exotic and expensive element that phosphoresces strongly. At the MRS meeting, Kennedy described how attaching an antibody to the particles can turn them into detectors that flag up environmental and biological toxicity. "These are exotic materials that haven't been made this way before," says Margaret Wooldridge, a mechanical engineer working on combustion synthesis at the University of Michigan, Ann Arbor.

Exploding droplets are themselves nothing new, says Kennedy - he was studying them in diesel fuel in the 1970s. But imaging techniques like Mädler's will give materials scientists a better understanding of how the explosions affect the properties of the materials produced. "This field is a bridge between combustion research and materials science," says Wooldridge. "It's growing, and you see a lot of younger people coming in." -

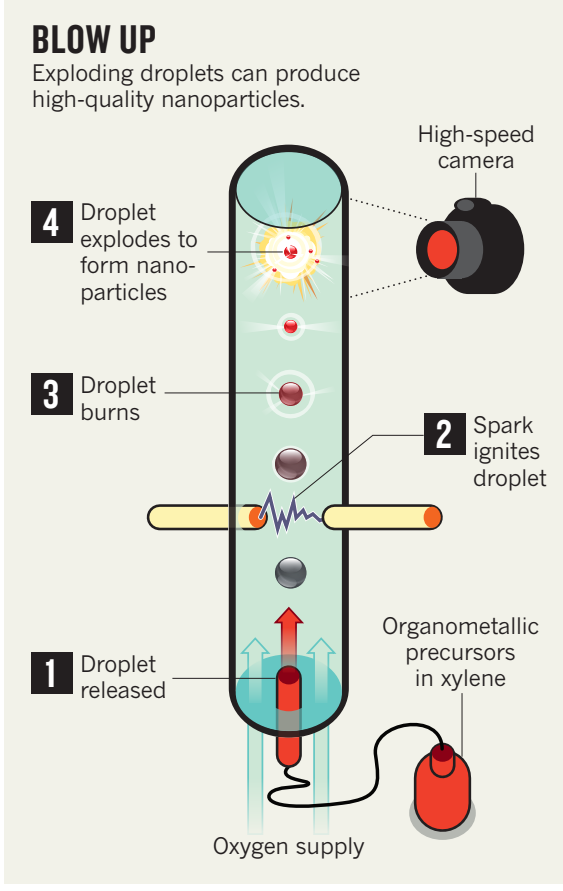

\section{Quiet Texan to head science committee}

\section{BY HELEN SHEN}

$\mathrm{S}$ cience advocates are cautiously hopeful after Lamar Smith, a quiet Texan who is known to be a strong supporter of US innovation, was named as the next chair of the Committee on Science, Space, and Technology in the US House of Representatives. Republican congressional leaders confirmed on 28 November that, in January, Smith will replace Ralph Hall, another Texas Republican, who is stepping down because of a party rule that limits a ranking member's tenure on a House committee to six years.

Smith will become the gatekeeper for much of the science-related legislation that reaches the House floor during the next Congress. Although successful House bills must also pass the Senate before becoming law, Smith - who has served on the committee for 26 years - will be "a key player in setting the agenda", says Scott Pace, director of the Space Policy Institute in Washington DC.

The choice was welcomed by technology advocates such as Keith Grzelak, vicepresident for government relations for the US arm of the Institute of Electrical and Electronics Engineers, based in Washington DC. "He understands the role that science, technology and engineering can play in boosting the economy," says Grzelak.

Smith spearheaded the America Invents Act of 2011, which aimed to simplify patent applications (see Nature 472, 149; 2011). He has also championed legislation to make immigration easier for foreign graduates with science, technology, engineering and mathematics degrees. "We can't have innovation without research and development," Smith said in a statement after his new role was announced.

Like many of his Republican colleagues, Smith has expressed doubts about the reality of anthropogenic global warming and has criticized the media for "a steady pattern of bias on climate change". But his tone has been more moderate than that of his challengers for the chairmanship, Dana
Rohrabacher (Republican, California) and committee vice-chairman Jim Sensenbrenner (Republican, Wisconsin). He is also less outspoken than Hall, who invited several staunch climate-change sceptics to testify before the committee last year. The committee faces a
number of pressing tasks next year, such as reauthorizing NASA - which includes setting the space agency's objectives and also the amount of money the government can appropriate for its operations. Also in need of reauthorization in 2013 will be the America COMPETES act, first passed in 2007. This seeks to enhance US competitiveness in the physical sciences with funding increases to key agencies onal Science Foundation and the Department of Energy's Office of Science.

The fate of America COMPETES will send a statement to the rest of the world about US research and development priorities, says Michael Lubell, director of public affairs at the American Physical Society in Washington DC. "If the signal is going to be the US cannot afford to do this," says Lubell, "I think that's going to be a big mistake." He hopes that Smith, who ultimately voted against reauthorization of America COMPETES in 2010, will support the measure this time and bring on board other Republicans - only 16 of whom supported the final version of the reauthorized act two years ago.

Eddie Bernice Johnson, a Texas representative who is the committee's top-ranking Democrat, hopes that Smith will quiet the partisan posturing on issues such as climate change and the role of the Environmental Protection Agency that marked Hall's chairmanship. "The selection of witnesses has been pretty one-sided," she says.

But fiscal concerns may play the biggest part in shaping Smith's decisions. The country is bracing itself for sweeping federal budget cuts in January unless Republicans and Democrats can reach a compromise on measures to reduce the deficit, and science would not escape the axe. 